\title{
Frog virus 3 prevalence in tadpole populations inhabiting cattle-access and non-access wetlands in Tennessee, USA
}

\author{
Matthew J. Gray ${ }^{1, *}$, Debra L. Miller ${ }^{2}$, A. Chandler Schmutzer ${ }^{1}$, Charles A. Baldwin ${ }^{2}$ \\ ${ }^{1}$ Center for Wildlife Health, Department of Forestry, Wildlife and Fisheries, University of Tennessee, \\ 274 Ellington Plant Sciences Building, Knoxville, Tennessee 37996-4563, USA \\ ${ }^{2}$ Veterinary Diagnostic and Investigational Laboratory, University of Georgia, 43 Brighton Road, Tifton, \\ Georgia 31793-1389, USA
}

\begin{abstract}
Ranaviruses have been associated with most of the reported larval anuran die-offs in the United States. It is hypothesized that anthropogenically induced stress may increase pathogen prevalence in amphibian populations by compromising immunity. Cattle use of wetlands may stress resident tadpole populations by reducing water quality. We isolated a Ranavirus from green frog Rana clamitans $(\mathrm{n}=80)$ and American bullfrog $R$. catesbeiana $(\mathrm{n}=104)$ tadpoles collected at 5 cattle-access and 3 non-access wetlands on the Cumberland Plateau, Tennessee, USA. Sequencing confirmed Frog virus 3 (FV3); therefore, we compared its prevalence between tadpole populations inhabiting cattle-access and non-access wetlands, and among 3 seasons (winter, summer, and autumn) in 2005. We found FV3 in both tadpole species and cattle land-use types; however, prevalence of FV3 was greater in green frog tadpoles residing in cattle-access wetlands compared to those in non-access wetlands. No difference in FV3 prevalence was detected between cattle land uses for American bullfrog tadpoles. A seasonal trend in FV3 prevalence also existed, with prevalence greater in autumn and winter than in summer for both species. In addition, we found that FV3 prevalence decreased significantly as Gosner stage increased in American bullfrog tadpoles. No trend was detected between FV3 prevalence and developmental stage for green frog tadpoles. Our results suggest that cattle use of wetlands may increase prevalence of FV3 in Rana tadpoles, although this effect may depend on species, season, and tadpole developmental stage.
\end{abstract}

KEY WORDS: Amphibian declines · Anthropogenic stressor - Emerging pathogen · Frog virus 3 . Cattle $\cdot$ Water quality

\section{INTRODUCTION}

Ranaviruses are responsible for some of the recent declines in amphibian populations (Carey et al. 2003, Greer et al. 2005), and are considered to be an emerging pathogen (Daszak et al. 1999). In the United States, ranaviruses have been implicated as the etiologic agent in the majority of reported amphibian dieoffs (Green et al. 2002). Anuran die-offs known to be caused by Ranavirus disease have occurred in at least 15 states of the United States and 11 species (Converse
\& Green 2005). Ranaviruses exist worldwide and at all elevations (Daszak et al. 1999, Converse \& Green 2005). Hence, this group of viruses is potentially a global threat to amphibian populations, especially if their prevalence is increased by anthropogenic stressors (Daszak et al. 2001, Carey et al. 2003).

Ranaviruses are most lethal to amphibian larvae (Gantress et al. 2003), with mortality rates often $>90 \%$ (Converse \& Green 2005). Ranavirus transmission has been documented via water bath (Brunner et al. 2004, Pearman et al. 2004, Harp \& Petranka 2006), cannibal- 
ism (Pearman et al. 2004, Harp \& Petranka 2006), proximity to infected individuals (Brunner et al. 2004), and exposure to virus-contaminated sediment (Harp \& Petranka 2006). Ranavirus disease is characterized by systemic hemorrhage and tissue necrosis, ultimately resulting in organ failure within only a few days of exposure (Converse \& Green 2005). The type species of the genus Ranavirus is Frog virus 3 (FV3), which was originally isolated from the northern leopard frog Rana pipiens in the mid-1960s (Granoff et al. 1965, Rafferty 1965). Since then, FV3 has been responsible for mass mortalities of wild and captive anuran populations in the United States, China, and Thailand (Carey et al. 2003, Miller et al. 2007), and is known to be lethal in at least one European species ( $R$. latastei; Pearman \& Garner 2005).

It is hypothesized that anthropogenic stressors will increase pathogen prevalence in amphibian populations by compromising their immunity (Carey et al. 1999, Daszak et al. 2003). For example, agricultural land use around wetlands may stress resident tadpoles by decreasing water quality. In particular, beef farming can decrease water quality in wetlands through deposition of nitrogenous waste by cattle (Hooda et al. 2000). Beef cattle often are given access to wetlands where amphibians breed to graze vegetation and drink water. Jancovich et al. (1997) reported emergence of the Ranavirus designated Ambystoma tigrinum virus in larval salamanders inhabiting a pond with cattle access. Therefore, for the present study, we hypothesized that cattle access in wetlands would increase FV3 prevalence in resident larval anuran populations.

Prevalence of ranaviruses in tadpole populations also may be influenced by natural environmental and developmental stressors. Maniero \& Carey (1997) reported a decrease in T-lymphocyte proliferation and serum-complement activity at low temperatures in northern leopard frogs. Rollins-Smith (1998) also provided evidence that tadpole immunity increases with development. Therefore, we further hypothesized that FV3 prevalence would be greatest during months with colder temperatures and during earlier tadpole developmental stages.

The objectives of our study were 2-fold. First, we wanted to compare FV3 prevalence between tadpoles collected at cattle-access and non-access wetlands and among 3 sample periods (15 February, 15 June, and 14 October 2005). Second, we wanted to relate FV3 prevalence with Gosner's (1960) developmental stage. This information is fundamental for understanding if cattle access in wetlands is a possible stressor of amphibian immunity, and whether this anthropogenic land use interacts with environmental and developmental stressors.

\section{MATERIALS AND METHODS}

Our study was conducted at the Plateau Research and Education Center (PREC) on the Cumberland Plateau near Crossville, Tennessee, USA $\left(36^{\circ} 00^{\prime} 59^{\prime \prime} \mathrm{N}\right.$, $\left.85^{\circ} 07^{\prime} 57^{\prime \prime} \mathrm{W}\right)$. We chose green frog Rana clamitans and American bullfrog $R$. catesbeiana tadpoles as our study species, because these species were relatively common at the PREC and have widespread distribution in the United States. In addition, these tadpole species are known to overwinter in Tennessee wetlands (Dodd 2004). We collected tadpoles opportunistically from 8 PREC wetlands using seine and dip nets during 3 sample periods (15 February, 15 June, and 14 October 2005) corresponding to 3 temperate seasons (winter, summer, and autumn, respectively). Four of our study wetlands had been exposed to cattle at a mean density of 19 head per 0.1 ha of water for $>10 \mathrm{yr}$. One additional wetland received cattle effluent via a natural drainage and was hence also classified as a cattle-access wetland. Three other wetlands that we sampled never had direct cattle access nor were connected hydrologically to cattle effluent; they were thus classified as non-access. All study wetlands were in close proximity to each other $(<0.4 \mathrm{~km}$ separation) and were similar in size ( 0.153 to $1.29 \mathrm{ha}$ ). In addition, they were permanently flooded in the center, $<2 \mathrm{~m}$ deep, and had emergent shoreline vegetation composed of cattail Typha latifolia, rushes (Juncaceae) and sedges (Cyperaceae).

We collected 80 green frog tadpoles from cattle-access and non-access wetlands ( $\mathrm{n}=47$ and 33, respectively) in June and October 2005 ( $\mathrm{n}=40$ each). No green frog tadpoles were captured in February 2005. We collected 104 American bullfrog tadpoles from cattle-access and non-access wetlands ( $\mathrm{n}=61$ and 43 , respectively) in February, June, and October $2005(\mathrm{n}=42,41$, and 21, respectively). Captured tadpoles were rinsed with sterile water and transported in separate containers to the University of Tennessee, where they were humanely euthanized within $24 \mathrm{~h}$ using benzocaine hydrochloride. Gosner's (1960) developmental stage was categorized following McDiarmid \& Altig (1999). All collection and euthanasia procedures followed the approved University of Tennessee Institutional Animal Care and Use Committee Protocol No. 1421 and were authorized under Tennessee Wildlife Resources Agency Scientific Collection Permit No. 1990.

Complete necropsies were performed immediately following euthanasia. Fresh tissue specimens of all organs (liver, spleen, kidney, intestines, heart, gills, lungs, eye, reproductive tissue, brain, skin, muscle) were collected for viral culture and PCR (polymerase chain reaction). An identical suite of tissues also was collected and placed in 10\% buffered formalin for 
paraffin embedding and to archive specimens. All specimens were subsequently transported overnight to the University of Georgia Veterinary Diagnostic and Investigational Laboratory in Tifton, Georgia, USA, for histological examination and viral testing.

To examine histopathological changes, formalinfixed tissues were routinely processed and embedded in paraffin blocks. One or more $5 \mu \mathrm{m}$ sections were cut from each block and placed on glass slides. Slides were stained with hematoxylin and eosin for light microscopic examination of viral inclusions and pathological changes.

For virus isolation, a single $10 \%$ tissue homogenate was made from all fresh tissue specimens for each tadpole, and filtered $(0.45 \mu \mathrm{m})$ directly onto confluent monolayers of a variety of cell lines, including fathead minnow, epithelioma papilloma cyprini cells, white sturgeon skin, and channel catfish ovary. Cultures demonstrating viral cytopathic effect were harvested and random isolates verified by electron microscopy (Fig. 1).

For PCR, a heminested procedure targeting the major capsid protein gene was performed on genomic DNA extracted from fresh and paraffin-embedded tissues following the protocol by Kattenbelt et al. (2000). In brief, the first-round reaction mixture $(25 \mu \mathrm{l}$, total volume) contained 50 to 100 pmol of the primers FV3991 (5'-CGCAGTCAAGGCCTTGATGT) and FV31571R (5'-AAAGACCCGTTTTGCAGCAAAC). For

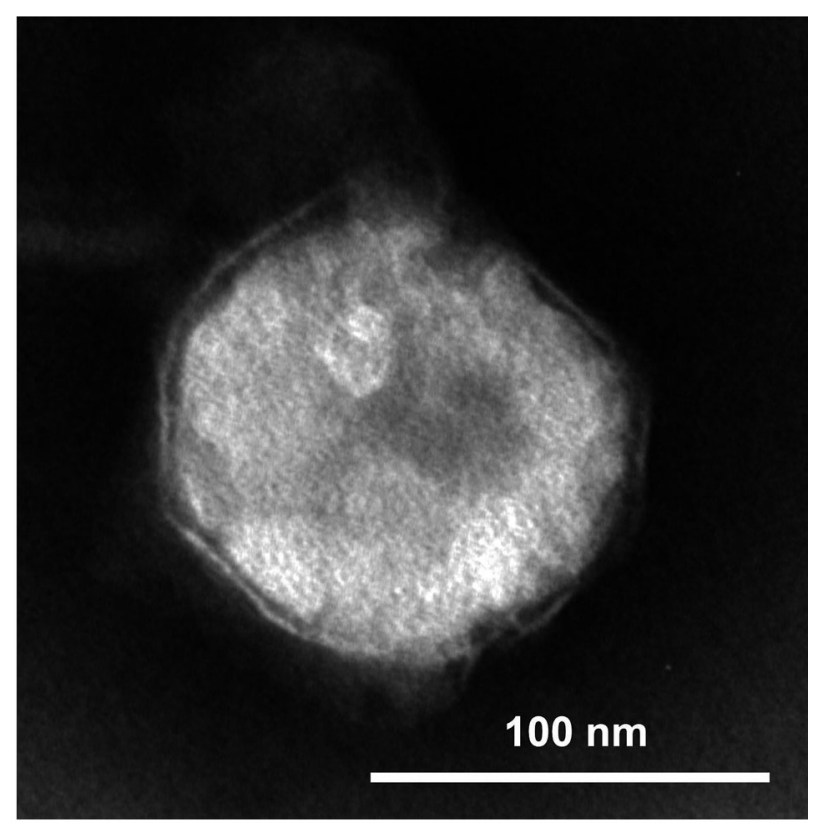

Fig. 1. Electron microscopy image of a Frog virus 3 isolate from a green frog Rana clamitans tadpole inhabiting a cattleaccess wetland, Plateau Research and Education Center, Tennessee, USA, 2005 this first round, the thermal cycler program was an initial denaturization step of $5 \mathrm{~min}$ at $94^{\circ} \mathrm{C}$, followed by 35 cycles of $1 \mathrm{~min}$ at $94^{\circ} \mathrm{C}, 1 \mathrm{~min}$ at $58^{\circ} \mathrm{C}$, and $1 \mathrm{~min}$ at $72^{\circ} \mathrm{C}$. The second-round reaction mixture $(25 \mu \mathrm{l}$, total volume) contained the primers P1050N (5'-TCAAGAGCGCCACGCTGGTGTA) and FV3-1571R. Only $0.5 \mu \mathrm{l}$ of the first-round product was carried over into the second-round PCR. For the second round, the thermal cycler program was an initial denaturization step of $10 \mathrm{~min}$ at $94^{\circ} \mathrm{C}$, followed by 25 cycles of $1 \mathrm{~min}$ at $94^{\circ} \mathrm{C}, 1 \mathrm{~min}$ at $58^{\circ} \mathrm{C}$, and $1 \mathrm{~min}$ at $72^{\circ} \mathrm{C}$. The PCR products were resolved by gel electrophoresis. The bands were isolated and submitted to SeqWright DNA Technology Services, Houston, Texas, USA, for automated sequencing. The resulting forward and reverse sequences were assembled using LaserGene Sequence Analysis Package (DNASTAR). A GenBank BLAST search was performed (www.ncbi.nlm.nih.gov/ genbank.html) on the consensus sequence (GenBank Reference No. DQ906048-49), and 100\% identity with the FV3 capsid protein gene and FV3 complete genome was found.

Prevalence of FV3 was tested between cattle-access and non-access land uses and among sampling dates for each species using logistic regression (Stokes et al. 2000). We included an interaction term in the model to test for non-additivity of land-use types and sampling date main effects. We also used logistic regression to test for a trend in FV3 prevalence among tadpole developmental stages for each species. Odds-ratio statistics were estimated to quantify the likelihood of FV3 infection in each cattle land-use type, and among sample periods and developmental stages. All analyses were performed using the $\mathrm{SAS}^{\circledR}$ system at $\alpha=0.05$ (Stokes et al. 2000).

\section{RESULTS}

A total of 80 green frog Rana clamitans tadpoles and 104 American bullfrog $R$. catesbeiana tadpoles were captured and used in FV3 analyses. Other tadpole species that were captured, but not collected, included spring peeper Pseudacris crucifer, northern cricket frog Acris crepitans, pickerel frog Rana palustris, American toad Bufo americanus, and Fowler's toad $B$. fowleri. Prevalence of FV3 was greater in cattle-access $(40 \%)$ than in non-access $(15 \%)$ wetlands for green frog tadpoles $\left(\chi^{2}{ }_{(1)}=5.2, p=0.02\right.$; Fig. 2). Odds-ratio estimates indicated that green frog tadpoles in cattleaccess wetlands were 3.9-fold more likely to be infected with FV3 than those in non-access wetlands. No difference was detected in FV3 prevalence between cattle land-use types for American bullfrog tadpoles $\left(\chi_{(1)}^{2}=0.08, p=0.78\right.$; Fig. 2). Also, cattle land 


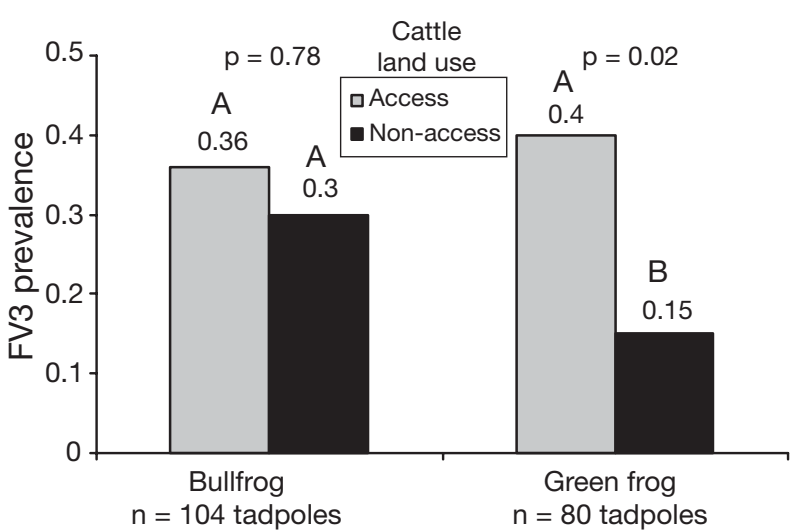

Fig. 2. Frog virus 3 (FV3) prevalence in American bullfrog Rana catesbeiana and green frog $R$. clamitans tadpoles at cattle-access and non-access wetlands, Plateau Research and Education Center, Tennessee, USA, 2005. Bars with unlike letters are significantly different $(p=0.02)$

uses and sampling period did not interact for either species $\left(\chi_{(1)}^{2}<0.98, \mathrm{p}>0.32\right)$, indicating that land-use effects were consistent among sampling periods.

FV3 prevalence was greater in winter (57\%) than in summer (15\%) and autumn (24\%) for American bullfrog tadpoles $\left(\chi^{2}{ }_{(2)}=15.9, \mathrm{p}<0.001\right.$; Fig. 3). Odds-ratio estimates indicated that American bullfrog tadpoles were 1.8- and 7.7-fold more likely to be infected with FV3 in autumn and winter than in summer, respectively. FV3 prevalence also was greater in autumn $(45 \%)$ than in summer $(15 \%)$ for green frog tadpoles $\left(\chi_{(1)}^{2}=7.5, p=0.006\right.$; Fig. 3). Odds-ratio estimates indicated that green frog tadpoles were 4.7 -fold more likely to be infected with FV3 in autumn than in summer. No green frog tadpoles were captured during winter for comparison.

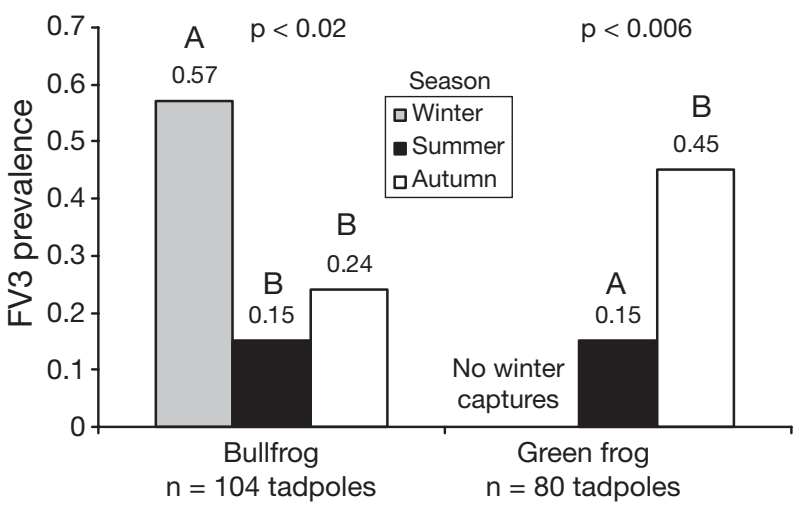

Fig. 3. Frog virus 3 (FV3) prevalence in American bullfrog Rana catesbeiana and green frog $R$. clamitans tadpoles collected on 15 February (winter), 15 June (summer), and 14 October (autumn) 2005, Plateau Research and Education Center, Tennessee, USA. Bars with unlike letters are significantly different $(p<0.02)$
FV3 prevalence was different among developmental stages for American bullfrog tadpoles $\left(\chi_{(1)}^{2}=12.8, \mathrm{p}<\right.$ 0.001; Fig. 4a). The predicted odds of FV3 infection decreased $28 \%$ with each unit increase in Gosner stage. No difference in FV3 prevalence was detected among developmental stages for green frogs $\left(\chi_{(1)}^{2}=\right.$ 0.71, $\mathrm{p}=0.87$; Fig. 4b).

\section{DISCUSSION}

Prevalence of FV3 was greater at cattle-access wetlands than at non-access wetlands for green frog Rana clamitans tadpoles. To our knowledge, this is the first evidence of a relationship between an anthropogenic land use and an emerging wildlife pathogen. The potential stressors of cattle land use are unknown, but may be related to water quality. In a concurrent study, Schmutzer (2007) documented that un-ionized ammonia concentration and turbidity were 3.2- and 4.6-fold greater, respectively, in cattle-access wetlands from March to August 2005. Dissolved oxygen also was $28 \%$ greater in non-access wetlands. We did not quantify physiological indicators of stress (e.g. blood cortisol) and immunocompetence (e.g. lymphocyte counts, serum complement), but decreased water quality in cattle-access wetlands may have stressed green frog tadpoles and facilitated FV3 infection. If this is true, we hypothesize that American bullfrog $R$. catesbeiana tad-

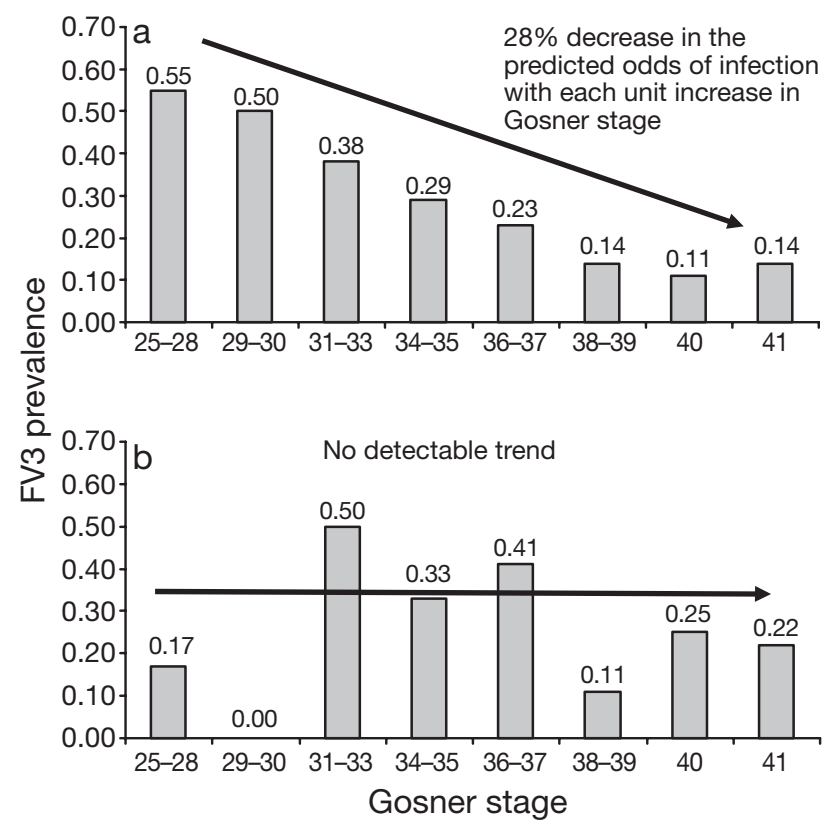

Fig. 4. Frog virus 3 (FV3) prevalence in: (a) American bullfrog Rana catesbeiana tadpoles $(\mathrm{n}=104)$ and $(\mathrm{b})$ green frog $R$. clamitans tadpoles $(\mathrm{n}=80)$ among Gosner developmental stages, Plateau Research and Education Center, Tennessee, USA, 2005. (a) $p=0.001$; (b) $p=0.872$ 
poles are more tolerant of low water quality than green frog $R$. clamitans tadpoles. More research is needed to understand the relationships of water quality, immune function, and FV3 infection among tadpole species.

We also found that FV3 prevalence was greater during colder months in green frog and American bullfrog tadpoles. Although this appears to be the first documentation of a seasonal trend in FV3 prevalence, Rojas et al. (2005) reported an increase in Ambystoma tigrinum virus virulence at lower temperatures. Forbes et al. (2004) also reported an increase in Aeromonas hydrophila prevalence in 3 ranid species during colder months. These authors hypothesized that increased virulence and infectivity were related to a decrease in immune function at colder temperatures (Forbes et al. 2004, Rojas et al. 2005). Cold-induced immunosuppression in amphibians has also been suggested by others (e.g. Carey et al. 1999, Raffel et al. 2006). Mean water temperature in our study wetlands during June 2005 was $25.1^{\circ} \mathrm{C}$ (Schmutzer 2007). Although we did not measure water temperature during February and October 2005, it is reasonable to assume that water temperature decreased in the order of June, October, and February, because Tennessee is located mid-latitude in the northern hemisphere. Mean ambient temperature at the PREC was $21.2,14.2$, and $5.1^{\circ} \mathrm{C}$ for these months, respectively (J. W. Hitch, PREC, unpubl. data). Other mechanisms for higher FV3 prevalence in winter may be related to exposure duration or increased scavenging of infected tadpoles (Pearman et al. 2004, Harp \& Petranka 2006).

Density of amphibian larvae has been suggested to be an important mechanism driving transmission of and infection by ranaviruses (Brunner et al. 2004). Relative abundance of green frog and American bullfrog tadpoles was 2.8- and 13.5-fold greater, respectively, in non-access wetlands from March to August 2005 and 2006 (Schmutzer 2007). We did not measure tadpole density in autumn or winter, but it is reasonable to assume that density during these seasons was lower than in summer, because most tadpole species in Tennessee metamorphose before October (Dodd 2004). Thus, tadpole density likely was not a factor driving cattle land-use and seasonal FV3 trends in our wetlands. Tadpole density in our wetlands ranged from 0.01 to 0.5 tadpoles $\mathrm{m}^{-2}$ (Schmutzer 2007). Similarly, Harp \& Petranka (2006) reported that survival of Ranavirus-infected wood frog Rana sylvatica tadpoles and time necessary to develop gross signs of Ranavirus disease were not related to tadpole density in a mesocosm experiment.

For American bullfrog tadpoles, FV3 prevalence decreased as Gosner stage increased. Several studies have suggested that amphibian larvae are more susceptible to Ranavirus infections than adults (Gantress et al. 2003, Brunner et al. 2005), perhaps due to the lack of major histocompatibility complex (MHC) Class I antigen expression in tadpoles, which is important in viral immune defense (Gantress et al. 2003). To our knowledge, however, this is the first field evidence of a trend in Ranavirus infection among Gosner developmental stages. This trend may be related to an increase in tadpole immune function with development (Rollins-Smith 1998). Several researchers have demonstrated an increase in lymphocyte numbers in Xenopus laevis during tadpole growth up to metamorphic climax (Rollins-Smith et al. 1984, Flajnik et al. 1987). Inasmuch as we observed this trend for American bullfrog tadpoles only, development of immune function during growth may be species specific (Rollins-Smith 2001), and interact with cattle land use. Indeed, this hypothesis needs to be tested. An alternative hypothesis is that American bullfrog tadpoles may be fatally infected at earlier development stages, resulting in survival of mostly uninfected individuals at later developmental stages.

\section{CONSERVATION IMPLICATIONS}

An increase in FV3 prevalence in amphibian populations is a conservation concern if infected individuals experience mortality or decreased fitness (Carey et al. 1999). Most available research suggests that the mortality rate of FV3-infected tadpoles is $>90 \%$ (Converse $\&$ Green 2005). We do not know if our infected tadpoles would have experienced mortality, because they were euthanized for collection. However, in a concurrent study, Burton (2007) observed that total capture of green frog metamorphs in pitfall traps at PREC cattleaccess wetlands was 3.7-fold less than at non-access wetlands from March to August 2005. Histological findings in our infected tadpoles included mild to occasionally moderate degeneration of renal tubular epithelial cells, mild lymphoid depletion in the thymus and other lymphoid tissues, and occasional intracytoplasmic inclusion bodies in erythrocytes, but morbidity was not observed. We also did not observe tadpole mortality events at the PREC wetlands, although this could have been a consequence of emergent vegetation along the shoreline limiting visibility or mortality events occurring when we were not present. Thus, we cannot draw any conclusions on whether an increase in FV3 prevalence increased the likelihood of population declines in our wetlands. Nonetheless, it is reasonable to assume that greater pathogen prevalence in a population will result in more disease occurrences. Currently, green frogs are not a species of concern in the United States; however, if less common species are influenced in a similar manner to green frogs, cattle 
grazing in wetlands could represent a conservation concern. More information is needed on the fate of FV3-infected tadpoles in cattle-access wetlands.

The United States leads the world in beef production (USDA 2006). Currently, there are approximately 98 million head of cattle on 1.1 million farms in the United States, with an annual production of 12 million $t$ of beef and veal products (USDA 2006). Many of these farms contain wetlands and ponds that amphibians and cattle use simultaneously. Knutson et al. (2004) reported the importance of farm wetlands for amphibians, because they often represent the only remnant habitat available. Some studies have reported a negative correlation between cattle access in wetlands and amphibian species richness and abundance (Healy et al. 1997, Jansen \& Healy 2003, Burton 2007, Schmutzer 2007). Indeed, more studies are needed examining the influences of cattle access in wetlands on resident amphibians. Given our FV3 results and the extensive cattle industry in the United States and other countries, beef farmers and land-use managers should consider fencing cattle from wetlands. Cattle use of wetlands and farm ponds likely represents an anthropogenic stressor of tadpole immunity for some species, and may contribute to global amphibian declines.

Our results also support previous concerns raised about the international transport of American bullfrogs for pet trade and aquaculture (e.g. Daszak et al. 2004). American bullfrog tadpoles can be sublethally infected with FV3, which could result in the introduction of this pathogen into naïve amphibian populations if infected individuals are released intentionally or unintentionally. Pearman \& Garner (2005) reported 50 to $100 \%$ mortality of naïve Italian agile frog Rana latastei tadpoles, depending on levels of genetic diversity. Their study illustrates the potential for catastrophic mortality events associated with introduction of FV3-infected American bullfrogs into naïve populations. A priori FV3 testing of live American bullfrogs should be considered as an export requirement in the United States.

Additional studies are needed on the impacts of water quality, temperature, and larval development on immune function and Ranavirus infection. The interaction of these factors and larval density also needs to be determined. In addition, large-scale surveillance is needed to improve our understanding of Ranavirus distribution and identify infection hotspots. Studies should include uncommon species, which have a greatest likelihood of extinction.

Acknowledgements. Funding for this study was provided by the University of Tennessee Institute of Agriculture, the University of Georgia Veterinary Diagnostic and Investigational Laboratory in Tifton, Georgia, and the Tennessee Wildlife Resources Agency. We especially thank J. W. Hitch and the
PREC staff for access to the study wetlands and for providing housing and other project logistics. We also thank the following individuals for assistance in tadpole collection, pathogen processing, or reviewing initial drafts of our manuscripts: K. Bridges, E. Burton, R. Cissell, C. Freeman, C. Grubb, J. Hamlington, D. Ingram, C. Langlais, A. Mathew, K. Mattocks, J. McCurry, G. Middleton, M. Parks, D. Rousey, R. Stratton, L. Whittington, and 3 anonymous peer referees.

\section{LITERATURE CITED}

Brunner JL, Schock DM, Davidson EW, Collins JP (2004) Intraspecific reservoirs: complex life history and the persistence of a lethal ranavirus. Ecology 85:560-566

Brunner JL, Richards K, Collins JP (2005) Dose and host characteristics influence virulence of ranavirus infections. Oecologia 144:399-406

Burton EC (2007) Influences of cattle on postmetamorphic amphibians on the Cumberland Plateau. MS thesis, University of Tennessee, Knoxville, TN

Carey C, Cohen N, Rollins-Smith L (1999) Amphibian declines: an immunologic perspective. Dev Comp Immunol 23:459-472

Carey C, Bradford DF, Brunner JL, Collins JP and 5 others (2003) Biotic factors in amphibian population declines. In: Linder G, Krest SK, Sparling DW (eds) Amphibian decline: an integrated analysis of multiple stressor effects. Society of Environmental Toxicology and Chemistry, Pensacola, FL, p 153-208

Converse KA, Green DE (2005) Diseases of tadpoles. In: Majumdar SK, Huffman JE, Brenner FJ, Panah AI (eds) Wildlife diseases: landscape epidemiology, spatial distribution and utilization of remote sensing technology. Pennsylvania Academy of Science, Easton, PA, p 72-88

Daszak P, Burger L, Cunningham AA, Hyatt AD, Green DE, Speare R (1999) Emerging infectious diseases and amphibian population declines. Emerg Infect Dis 5: 735-748

Daszak P, Cunningham AA, Hyatt AD (2001) Anthropogenic environmental change and the emergence of infectious diseases in wildlife. Acta Trop 78:103-116

Daszak P, Cunningham AA, Hyatt AD (2003) Infectious disease and amphibian population declines. Diversity Distrib 9:141-150

Daszak P, Strieby A, Cunningham AA, Longcore JE, Brown CC, Porter D (2004) Experimental evidence that the bullfrog (Rana catesbeiana) is a potential carrier of chytridiomycosis, an emerging fungal disease of amphibians. Herpetol J 14:201-207

Dodd CK Jr (2004) The amphibians of Great Smoky Mountains National Park. University of Tennessee, Knoxville, TN

Flajnik MF, Hsu E, Kaufman JF, Du Pasquier L (1987) Changes in the immune system during metamorphosis of Xenopus. Immunol Today 8:58-64

Forbes MR, McRuer DL, Rutherford PL (2004) Prevalance of Aeromonas hydrophila in relation to timing and duration of breeding in three species of ranid frogs. Ecoscience 11: 282-285

Gantress J, Maniero GD, Cohen N, Robert J (2003) Development and characterization of a model system to study amphibian immune responses to iridoviruses. Virology 311:254-262

Gosner KL (1960) A simplified table for staging anuran embryos and larvae with notes on identification. Herpetologica 16:183-190 
Granoff A, Came PE, Rafferty KA (1965) The isolation and properties of viruses from Rana pipiens: their possible relationship to the renal adenocarcinoma of the leopard frog. Ann NY Acad Sci 126:237-255

Green DE, Converse KA, Schrader AK (2002) Epizootiology of sixty-four amphibian morbidity and mortality events in the USA, 1996-2001. Ann NY Acad Sci 969:323-339

Greer AL, Berrill M, Wilson PJ (2005) Five amphibian mortality events associated with ranavirus infection in south central Ontario, Canada. Dis Aquat Org 67:9-14

Harp EM, Petranka JW (2006) Ranavirus in wood frogs (Rana sylvatica): potential sources of transmission within and between ponds. J Wildl Dis 42:307-318

Healey J, Thompson D, Robertson A (1997) Amphibian communities associated with billabong habitats on the Murrumbidgee floodplain, Australia. Aust J Ecol 22:270-278

Hooda PS, Edwards AC, Anderson HA, Miller A (2000) A review of water quality concerns in livestock farming areas. Sci Total Environ 250:143-167

Jancovich JK, Davidson EW, Morado JF, Jacobs BL, Collins JP (1997) Isolation of a lethal virus from the endangered tiger salamander Ambystoma tigrinum stebbinsi. Dis Aquat Org 31:161-167

Jansen A, Healey M (2003) Frog communities and wetland conditions: relationships with grazing by domestic livestock along an Australian floodplain river. Biol Conserv 109:207-219

Kattenbelt JA, Hyatt AD, Gould AR (2000) Recovery of ranavirus dsDNA from formalin-fixed archival material. Dis Aquat Org 39:151-154

Knutson MG, Richardson WB, Reinecke DM, Gray BR, Parmelee JR, Weick SE (2004) Agricultural ponds support amphibian populations. Ecol Appl 14:669-684

Maniero GD, Carey C (1997) Changes in selected aspects of immune function in the leopard frog, Rana pipiens, associated with exposure to cold. J Comp Physiol B 167:256-263

McDiarmid RW, Altig R (1999) Tadpoles: the biology of anuran larvae. University of Chicago, Chicago, IL

Editorial responsibility: Alex Hyatt,

Geelong, Victoria, Australia
Miller DL, Rajeev S, Gray MJ, Baldwin CA (2007) Frog virus 3 infection, cultured American bullfrogs. Emerg Infect Dis 13:342-343

Pearman PB, Garner TWJ (2005) Susceptibility of Italian agile frog populations to an emerging strain of Ranavirus parallels population genetic diversity. Ecol Lett 8:401-408

Pearman PB, Garner TWJ, Straub M, Greber UF (2004) Response of the Italian agile frog (Rana latastei) to a Ranavirus, frog virus 3: a model for viral emergence in naïve populations. J Wildl Dis 40:660-669

Raffel TR, Rohr JR, Kiesecker JM, Hudson PJ (2006) Negative effects of changing temperature on amphibian immunity under field conditions. Funct Ecol 20:819-828

Rafferty KA (1965) The cultivation of inclusion-associated viruses from Lucke tumor frogs. Ann NY Acad Sci 126: $3-21$

Rojas S, Richards K, Jancovich JK, Davidson EW (2005) Influence of temperature on Ranavirus infection in larval salamanders Ambystoma tigrinum. Dis Aquat Org 63: 95-100

Rollins-Smith LA (1998) Metamorphosis and the amphibian immune system. Immunol Rev 166:221-230

Rollins-Smith LA (2001) Neuroendocrine-immune system interactions in amphibians: implications for understanding global amphibian declines. Immunol Res 23(2/3):273-280

Rollins-Smith LA, Parsons SCV, Cohen N (1984) During frog ontogeny, PHA and Con A responsiveness of splenocytes precedes that of thymocytes. Immunology 52:491-500

Schmutzer AC (2007) Influences of cattle on community structure and pathogen prevalence in larval amphibians on the Cumberland Plateau, Tennessee. MS thesis, University of Tennessee, Knoxville, TN

Stokes ME, Davis CS, Koch GG (2000) Categorical data analysis using the SAS system, 2nd edn. SAS Institute, Cary, NC

USDA (US Department of Agriculture) (2006) Global beef statistics. Available at: www.fas.usda.gov/dlp/livestock_ poultry.asp

Submitted: December 1, 2006; Accepted: June 13, 2007 Proofs received from author(s): August 21, 2007 